Review Article

\title{
Spatial and Temporal Distribution of Large Igneous Provinces in the Indian Shield - Highlights of Recent Investigations
}

\author{
RAJESH K SRIVASTAVA ${ }^{1, *}$, AMIYA K SAMAL ${ }^{1}$, RICHARD E ERNST ${ }^{2,3}$, ULF SÖDERLUND ${ }^{4}$ and RAVI \\ SHANKAR ${ }^{5}$ \\ ${ }^{1}$ Centre of Advanced Study in Geology, Institute of Science, Banaras Hindu University, Varanasi 221 \\ 005 , India \\ ${ }^{2}$ Department of Earth Sciences, Carleton University, Ottawa, ON K1S5B6, Canada \\ ${ }^{3}$ Faculty of Geology and Geography, Tomsk State University, 36 Lenin Ave, Tomsk 634050, Russia \\ ${ }^{4}$ Department of Geology, Lund University, Sölvegatan 12, SE-223 62 Lund, Sweden \\ ${ }^{5}$ CSIR-National Geophysical Research Institute, Uppal Road, Hyderabad 500 007, India
}

(Received on 20 August 2019; Accepted on 29 September 2019)

\begin{abstract}
This report highlights investigations since 2016 on the Large Igneous Provinces (LIPs), particularly based on their mafic dyke swarms (MDSs) and continental flood basalts (CFBs), from the Indian Shield. Recent research, particularly geochemistry, geochronology and paleomagnetism, allow identification and characterization of distinct generations of LIPs in space and time in the Indian Shield. This could be the basis for critical new tests of paleogeographic reconstructions of supercontinents and paleocontinents of the Earth's history and the position of India in different ancient supercontinent/supercratons. The high-quality data generated in recent years also helped significantly to understand the nature, composition and evolution of the sub-continental lithospheric mantle beneath the Indian Shield, which aims at resolving important geological aspects, such as the role of plume tectonics, ancient subduction events, extent of the LIPs paleo-supercontinent reconstructions, etc., and has received considerable national and international attention.
\end{abstract}

Keywords: Large Igneous Provinces; Geochemistry; Geochronology; Paleomagnetism; Mafic Dyke Swarms; Continental Flood Basalts; Indian Shield

\section{Introduction}

Large Igneous Provinces (LIPs) represent large volume $\left(>0.1 \mathrm{Mkm}^{3}\right)$, mainly mafic (-ultramafic) magmatic events of intraplate affinity that occur in both continental and oceanic settings and are typically of short duration $(<1$ myr) or consist of multiple short pulses over a maximum of a few 10s of myr (cf. Bryan and Ferrari, 2013; Ernst, 2014). LIPs may comprise continental flood basalts (CFBs), and a plumbing system of mafic dyke swarms (MDSs), sill complexes, layered intrusions, and crustal magmatic underplating, although erosion and deformation over time means that an individual LIP may incompletely preserve some of these components. LIPs can also be associated with silicic magmatism (known as Silicic LIPs, or SLIPs; when the size reaches LIP-scale), carbonatites and kimberlites and could be linked with continental breakup, regional domal uplift, global climate change including extinction events (e.g. Ernst and Youbi, 2017). Moreover, it represents significant reservoirs of energy and metals that can either drive or contribute to a variety of metallogenic systems, and also affect hydrocarbon and aquifer systems as well (cf. Ernst and Jowitt, 2017). The relationships between LIPs and the generation of multiple different types of mineral, water and hydrocarbon resources are only useful to industry if exploration strategies can be developed that take advantage of the LIP record and variations in the characteristics (e.g. geochemistry) of individual LIPs (Ernst and Jowitt, 2017). 'Barcoding' the geological record, particularly identifying LIP events, allows, in principle, the

\footnotetext{
*Authorfor Correspondence: E-mail: rajeshgeolbhu@gmail.com
} 
possibility of a full reconstruction of Earth's paleogeography of continents, back to ca. $2.7 \mathrm{Ga}$ (cf. Bleeker and Ernst, 2006; Ernst, 2014).

LIPs are primarily represented by large volume mafic magmatic events, particularly MDSs and CFBs. However, for many reasons including their great vertical depth and lateral extent, MDSs in shield areas provide the most complete record of such magmatism through time and space (cf. Srivastava et al., 2010, 2019a; Ernst, 2014; Peng et al., 2016, 2019; Sensarma et al., 2018). CFBs are more common in Phanerozoic LIPs, but are present only as erosional remnants during the Precambrian where the LIP plumbing system of MDSs provides a robust record of the rhythm of intraplate mantle melting events; this includes riftrelated events to the largest known igneous events on the planet (cf. Ernst, 2014). More importantly, if such MDS events are linked with precise ages, they become an incomparable source of information on several geological and geodynamic aspects, such as tectonics, secular evolution of the mantle, age and location of igneous centres, paleo-stress directions, key paleomagnetic poles, paleo-intensities of the core dynamo, plume frequency, mantle sources, etc. and subsequently reconstruction of ancient supercontinents (cf. Srivastava et al., 2010, 2019a; Srivastava, 2011; Ernst, 2014; Ernst and Jowitt, 2017; Ernst and Youbi 2017; Sensarma et al., 2018; Peng et al., 2016, 2019).

The different cratonic regions of the Indian Shield have an extensive record of large magmatic events (LIPs) from Precambrian to Paleogene, and are also thought to be an integral part of several ancient supercontinents (cf. Ernst, 2014; Sensarma et al., 2018; Roy and Purohit, 2018; Samal et al., 2019a,b). Precambrian mafic magmatic events are mostly represented by extensive emplacement of mafic dyke swarms (Srivastava et al., 2016a; Samal et al., 2019a). A number of recent publications (since 2016) provide comprehensive information on geochemistry, geochronology, and paleomagnetism of the different components of LIPs from the different Indian cratons, mobile belts and sedimentary basins of the Indian Shield (see Fig. 1). Similar to the known LIPs of the globe, LIP events of the Indian Shield can also be correlated with distinct metallogenic systems (cf. Srivastava et al., 2018; Nehru and Sikka, 2018). Glimpses of all these findings, into two major groups i.e. (i) Precambrian and (ii) Phanerozoic LIPs, are summarized in the subsequent sections.

\section{Precambrian LIPs}

Broadly, the Indian Shield comprises twelve LIP events during Precambrian (cf. Ernst and Srivastava, 2008; Ernst, 2014; Samal et al., 2019a,b; see Table 1). Based on the recent investigations, salient geochronological, geochemical and paleomagnetic highlights of these LIPs are described below.

\section{Geochronology}

A number of recent publications report geochronological data, mostly precisely dated, particularly using the U-Pb methods, of distinct magmatic events of the Indian Shield (Kumar et al., 2017; Samom et al., 2018; Shellnutt et al., 2018, 2019; Nagaraju et al., 2018a,b; Srivastava et al., 2019b; Söderlund et al., 2019; Liao et al., 2019) and these are well summarized in Samal et al. (2019a,b).

Söderlund et al. (2019) have refined the LIP record of the Dharwar craton through ID-TIMS U$\mathrm{Pb}$ baddeleyite ages of different generations of mafic dykes. On the basis of these new eighteen Paleoproterozoic ages together with ages reported in other recent publications (Nagaraju et al., 2018a,b; all other available ages are compiled in Söderlund et al., 2019; Samal et al., 2019a,b), they identified eight different dyke swarms with emplacement ages between 2.37 and $1.79 \mathrm{Ga}$ across the eastern Dharwar Craton (see Table 1 for their respective LIPs).These include:

1. NE-SW to ESE-WNW trending ca. $2.37 \mathrm{Ga}$ Bangalore-Karimnagar swarm,

2. $\mathrm{N}-\mathrm{S}$ to $\mathrm{NNE}-\mathrm{SSW}$ trending ca. $2.25 \mathrm{Ga}$ Ippaguda-Dhiburahalli swarm,

3. $\mathrm{N}-\mathrm{S}$ to $\mathrm{NNW}-\mathrm{SSE}$ trending ca. $2.22 \mathrm{Ga}$ Kandlamadugu swarm,

4. NW-SE to WNW-ESE trending ca. 2.21 Ga Anantapur-Kunigal swarm,

5. NW-SE to WNW-ESE trending ca. $2.18 \mathrm{Ga}$ Mahbubnagar-Dandeli swarm,

6. N-S, NW-SE, and ENE-WSW trending ca. 2.08 Ga Devarabanda swarm, 


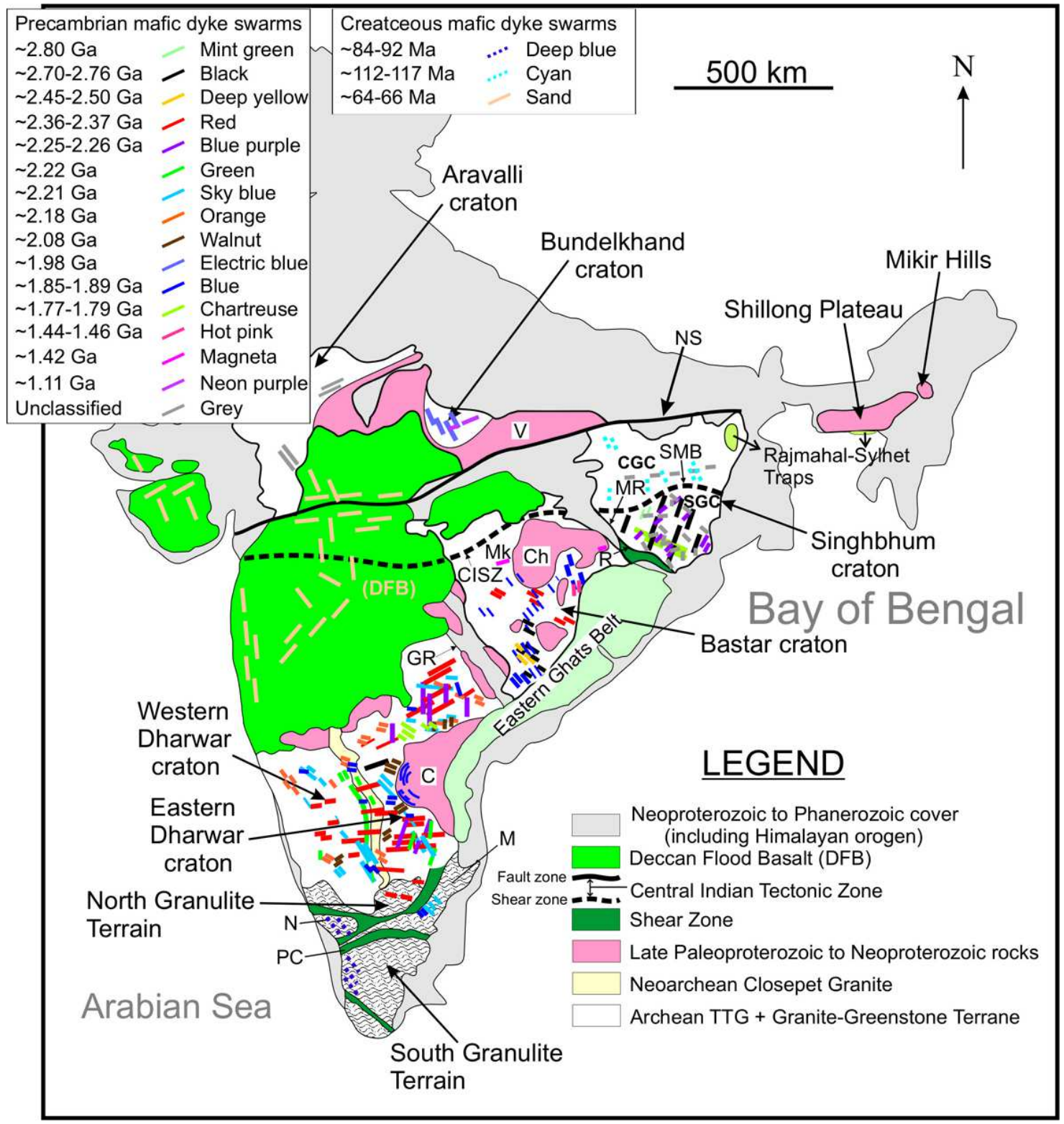

Fig. 1: Generalized geological map showing distinct Precambrian and Cretaceous mafic dyke swarms (MDSs) and Cretaceous continental flood basalts (CFBa) in different Cratons of the Indian Shield (Figure modified and taken from Samal et al., 2019a,b). Other major geological features: Ch, Chattisgarth Basin; CIS, Central Indian Shear Zone; CGC, Chhotanagpur Gneissic Complex; GR, Godavari Rift; M, Madras Block; Mk, Malanjkhand; MR, Mahanadi Rift; N, Nilgiri Block; NS, Narmada-Son Fault Zone; PCSZ, Palghat-Cauvery Shear Zone; R, Rengali Province and Kerajang Shear Zone; SGC, Singhbhum Granite Complex, SMB, Singhbhum Mobile Belt; V, Vindhyan Basin

7. E-W trending ca. 1.88-1.89 Ga Hampi swarm, and

8. NW-SE ca. 1.79 Ga Pebbair swarm.

Besides the identification of these Paleoproterozoic mafic dyke swarms and their respective LIPs, Söderlund et al. (2019) have also observed and offered reasons for bending of several
Archean-Paleoproterozoic geological features such as (i) $450-500 \mathrm{~km}$ long N-S dyke (part of the ca. 2.22 Ga Kandlamadugu swarm), (ii) 2.62-2.52 Ga Closepet Granite batholiths, and (iii) 3.4-2.7 Ga greenstone belts, which have experienced a $30^{\circ}$ relative rotation between northern and centralsouthern parts of the eastern Dharwar craton. They suggested that this tectonic bending observed between 
the northern and southern Dharwar craton could be related either to orthogonal extension of its eastern convex side or a zone of pervasive dextral shearing affecting its southern portion. The three major dyke swarms in the eastern Dharwar craton (EDC) viz. ca. 2.37 Ga Bangalore-Karimnagar, ca. 2.25 Ga Ippaguda-Dhiburahalli, and ca. 2.21 Ga AnantapurKunigal, which become approximately linear swarms after correction for the tectonic bending (see Fig. 2), and if correct, then previous interpretations of plume centre location as well as paleoreconstructions, based on a radiating pattern for these swarms are probably incorrect (Söderlund et al., 2019).

Pivaranus et al. (2018) dated a mafic dyke from NW of the Krishnagiri, Northern Granulite Terrain (NGT) that yields crystallization age of $2363 \pm 6.6 \mathrm{Ma}$. This work supports the extension of ca. 2.37 Ga LIP towards the southern region of the eastern Dharwar craton. One additional dyke swarm i.e. $\sim 1.85-1.86$ Ga Dharmapuri swarm is now recognized (cf. Shellnutt et al., 2019; Samal et al., 2019b), which could be potentially a part of the previously recognized ca. 1.88-1.89 Ga Hampi swarm. This is based on magmatic events recorded in the entire Dharwar craton, which includes NW-SE trending mafic dykes (Belica et al., 2014; as described in Shellnutt et al., 2019) and felsic tuffs from the upper part of the Tadpatri formation of the Cuddapah basin (Sheppard et al., 2017).

In recent years, the record of Paleoproterzoic mafic dyke swarms has also expanded in the Bastar craton (Shellnutt et al., 2018, 2019; Liao et al., 2019). Shellnutt et al. (2018) obtained a ${ }^{207} \mathrm{~Pb} /{ }^{206} \mathrm{~Pb}$ age of 1882.4 $\pm 1.5 \mathrm{Ma}$ on a NW trending tholeiitic dyke in the Bhanupratappur region and linked it with the Bastanar swarm of the Bastar craton and the Hampi swarm of the Dharwar craton (cf. Samal et al., 2019a). This enabled a linkage between the Bastar and Dharwar cratons has been established (Shellnutt et al., 2018). Another dyke from the same area, i.e. near Bhanupratapppur, yields an older age (Liao et al., 2019); they obtained a ${ }^{207} \mathrm{~Pb} /{ }^{206} \mathrm{~Pb}$ age of $2365.6 \pm 0.9 \mathrm{Ma}$ on a boninitic dyke that is now termed the Bhanupratappur swarm (Samal et al., 2019b). Further, the chemical and temporal similarities between the Bhanupratappur swarm of the Bastar craton and the ca. 2.37 Ga Bangalore-Karimnagar swarm of the Dharwar craton have been established, which suggest connection between these two swarms as a giant dyke swarm. However, it is further explained that although these two cratons were adjacent to each other that they likely had a different configuration at $2.37 \mathrm{Ga}$ than the present day (cf. Liao et al., 2019).

A slightly younger dyke swarm, viz. Sonakhan swarm was also discovered from the NW part of the Bastar craton; a NW mafic dyke exposed near Sonakhan yielded a weighted-mean ${ }^{207} \mathrm{~Pb} /{ }^{206} \mathrm{~Pb}$ baddeleyite age of $1851.1 \pm 2.6 \mathrm{Ma}$ (Shellnutt et al., 2019). An apparent connection between the Paleoproterzoic mafic dyke swarms i.e. (i) the ca. 1.88-1.89 Ga Bastanar and ca. 1.85 Ga Sonkhan swarms of the Bastar craton, (ii) the ca. 1.88-1.89 Ga Hampi and ca. 1.85-1.86 Ga Dharmapuri swarms of the Dharwar craton, and (iii) the ca. $1.89 \mathrm{Ga}$ Boonadgin and ca. 1.85 Ga Yalgoo dykes of the Yilgarn craton has been suggested (Stark et al., 2019; Shellnutt et al., 2019; Samal et al., 2019b). These swarm correlations are supportive of India and Western Australia being in connection during the Paleoproterozoic (see Fig. 3) and all these magmatic activities together with poorly dated ca. 1.80-1.90 Ga mafic intrusive rocks within the Himalayan Mountain Range are also thought to be part of the shared ca. 1.85-1.90 Ga LIP event (Srivastava and Samal, 2019; Samal et al., 2019a,b).

Besides mafic dykes, other units of LIPs from the Bastar craton have also been dated. Santosh et al. (2018) reported a U-Pb zircon age of $2473 \pm 8 \mathrm{Ma}$ for a syenitic body exposed near the Nuapada, which probably represent thermal events associated with the ca. 2.4-2.5 Ga Dantewara LIP event (Samal et al., 2019a). Chalapathi Rao et al. (2016) have reported ${ }^{40} \mathrm{Ar} /{ }^{39} \mathrm{Ar}$ whole-rock age of $1045 \pm 9 \mathrm{Ma}$ for a lamproite intrusion, which is thought to be related with the widespread alkaline and mafic magmatism of the Indian Shield $\sim 1.05-1.11$ Ga (cf. Samal et al., 2019a,b).

The Singhbhum Granite Complex (SGC), an integral part of the Singhbhum craton, also witnessed extensive mafic magmatism, including 'Newer' dolerites, during the Precambrian and geochronology of some of these events are reported recently (cf. Srivastava et al., 2019b; Samal et al., 2019a). Kumar et al. (2017) reported $\mathrm{Pb}-\mathrm{Pb}$ baddeleyite ages for the 


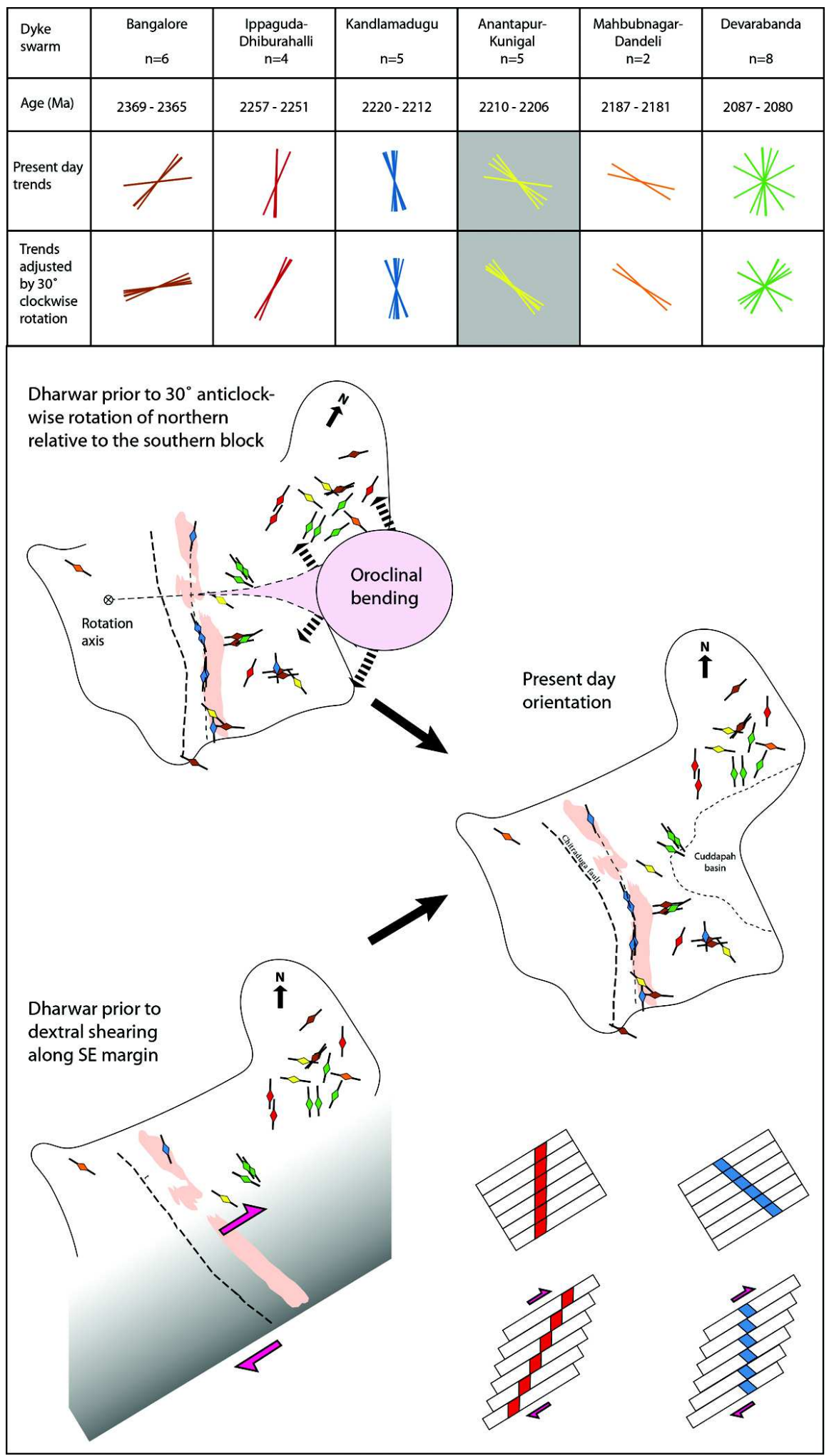

Fig. 2: The Dharwar craton shown in present day orientation (right) and prior to two tectonicmodels (left) to explain a $30^{\circ}$ clockwise rotation from north to south of basement geological features and dyke swarms: orthogonal extension of its eastern convex side (upper left) or pervasive dextral shearing within its southern portion (lower left). Rose diagrams on top of the figure show the change before and after dykes have been adjusted by $30^{\circ}$ relative rotation. The effect of dextral shearing is exemplified by two dykes of the $\mathrm{N}-\mathrm{S}$ and $\mathrm{NW}-\mathrm{SE}$ trending Ippaguda-Dhiburahalli (red) and Kandlamadugu swarms (blue), respectively (lower right). Figure taken from Söderlund et al. (2019) 



Fig. 3: Conceptual model of rift propagation from $1.88 \mathrm{Ga}$ to $1.85 \mathrm{Ga}$. The left diagram shows the initial rift and magmatism begin at $\sim 1.88 \mathrm{Ga}$ as Peninsular India and Western Australia are proximal and the right diagram shows that extension continues and rift propagates NE-ward and the younger dykes are emplaced at $\sim 1.85$ Ga (Figure taken from Stark $e t$ al., 2018; Shellnutt et al., 2019)

NNE-SSW trending mafic dykes exposed in the entire SGC, which are grouped into two dyke swarms i.e. (i) the ca. $2.80 \mathrm{Ga}$ Keshargaria swarm and (ii) the ca. 2.75-2.76 Ga Ghatgaon swarm (Samal et al., 2019a,b). These two swarms are comparable with similar magmatic events recorded in the Kaapvaal and Pilbara cratons during the Neoarchean (Kumar et al., 2017) and represent part of a ca. $2.75-2.80 \mathrm{Ga}$ global LIP event. Later, a U-Pb ID-TIMS emplacement age of $2256 \pm 6 \mathrm{Ma}$ was reported for the NE-SW to ENE-WSW trending Kaptipada mafic dyke swarm (Srivastava et al., 2019b). Earlier, Shankar et al. (2014) obtained a ca. $1.77 \mathrm{Ga}$ U-Pb age for WNE-ESE mafic dykes belonging to the Pipilia swarm. On the basis of integration of dyke trends, cross-cutting relationships, and available geochronological data, the mafic dykes of the SGC have been classified into seven distinct swarms, which interpreted to represent LIP events (Srivastava et al. 2019b; Samal et al., 2019a,b). These include -

1. NE-SW trending ca. $2.80 \mathrm{Ga}$ Keshargaria swarm,

2. NNE-SSW to NE-SW trending ca. 2.75-2.76 Ga Ghatgaon swarm,

3. NE-SW to ENE-WSW ca. 2.26 Ga trending Kaptipada swarm,

4. WNW-ESE trending ca. 1.77 Ga Pipilia swarm,
5. E-W to ENE-WSW trending earlyPaleoproterozoic Keonjhar swarm,

6. NW-SE to NNW-SSE trending middlePaleoproterozoic Bhagamunda swarm, and

7. N-S to NNE-SSW trending latePaleoproterozoic Barigaon swarm.

Srivastava et al. (2019b) successfully correlated the ca. 2.26 Ga Kaptipada and ca. 1.77 Ga Pipilia swarms of the SGC with the ca. 2.26-2.25 Ga Ippaguda-Dhiburahalli and $1788 \mathrm{Ma}$ Pebbair swarms of the eastern Dharwar craton and suggested that these two blocks were nearby during this interval. They also inferred that these two swarms should be present in the intervening Bastar craton too (see Fig. 4). Furthermore, these two swarms also match globally to ca. $2.25 \mathrm{Ga}$ swarms in Antarctica, Kaapvaal and Zimbabwe cratons, and at ca. 1.79-1.77 Ga with LIP events in North China, Northern Australia, Amazonia and Sarmatia cratons suggesting a reconstruction connection with these ca. 2.25-2.26 Ga and ca. 1.771.79 Ga global LIP events, respectively (cf. Srivastava et al., 2019b).

The mafic volcanic rocks exposed in the SGC are also thought to be associated with some of the SGC mafic dyke swarms (Srivastava et al., 2016b; Srivastava et al., 2019b,c; Mazumder and Chaudhuri, 2019). The ca. $2.80 \mathrm{Ga}$ Dhanjori mafic volcanic rocks could be correlated with the ca. 2.75-2.80 Ga LIP. 


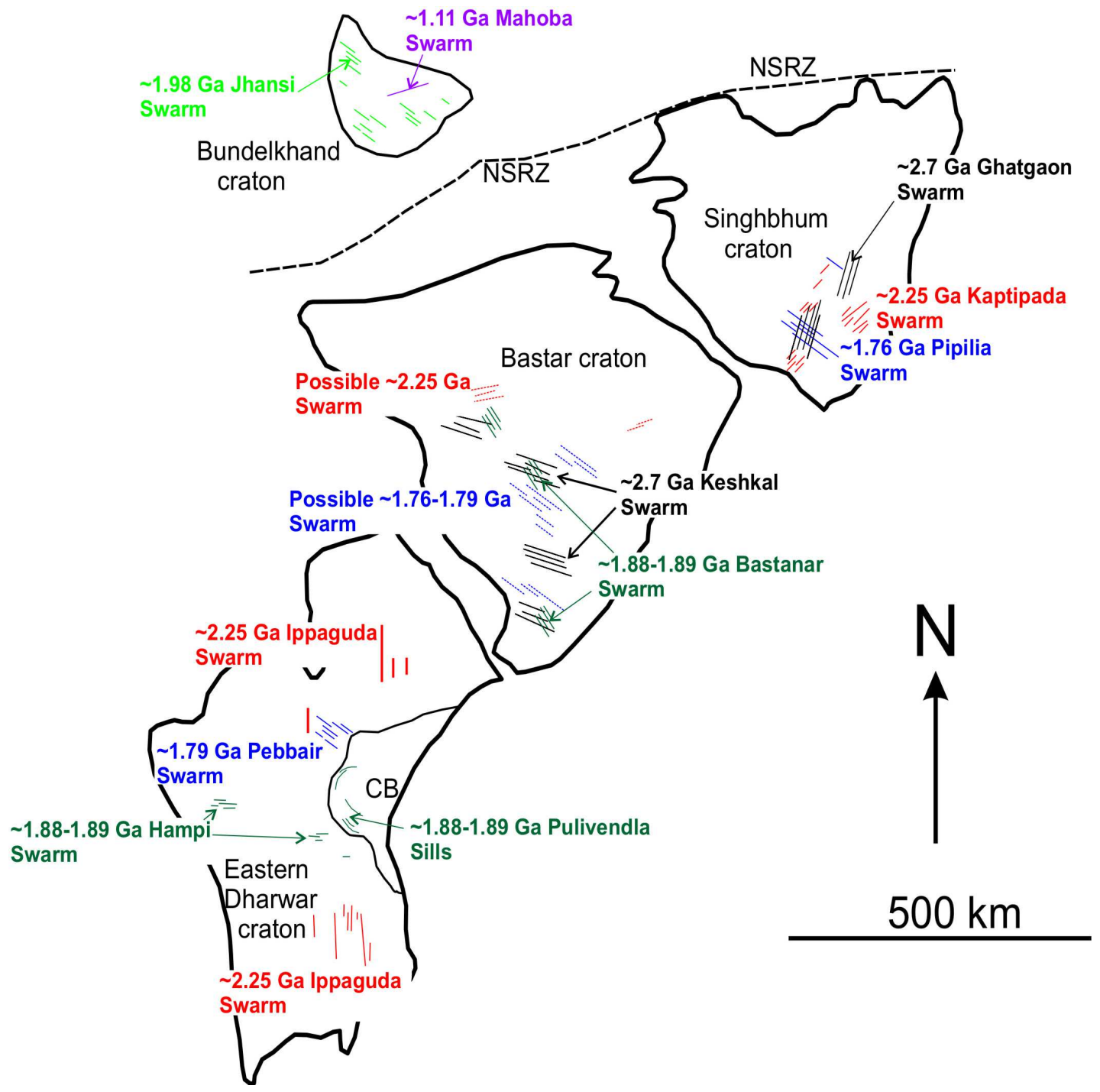

Fig. 4: Present day configuration of ca. 2.7 Ga, ca. 2.25 Ga, ca. 1.88-1.89 Ga, ca. 1.77-1.79 Ga and ca. 1.10-1.12 Ga mafic dyke swarms and sills and associated kimberlite/lamproite intrusions in the Dharwar (EDC), Bastar, Singhbhum and Bundelkhand cratons. NSRZ = Narmada-Son Rift Zone. Figure taken from Srivastava et al. (2019b) and Söderlund et al. (2019)

The Dalma mafic volcanic are estimated be ca. 1.7 $\mathrm{Ga}$ and therefore, could be correlated with the ca. 1.77 Ga Pipilia swarm and also be part of the ca. 1.77-1.79 Ga LIP (Srivastava et al., 2019b,c; Mazumder and Chaudhuri, 2019). The age of two other basic volcanic units, namely the Jagannathpur and the Malangtoli, have been estimated ca. $2.25 \mathrm{Ga}$ ( $\mathrm{Pb}-\mathrm{Pb}$ age) and, therefore could be connected with the ca. 2.26 Ga Kaptipada mafic dyke swarm, which can be a part of ca. 2.25-2.26 Ga LIP of the Indian Shield and other blocks noted above (Srivastava et al., 2019b,c; Mazumder and Chaudhuri, 2019).
Based on available ages and trends, the mafic dykes of the Bundelkhand craton have been classified into two distinct mafic dyke swarms viz. (i) NW-SE trending ca. 1.98 Ga Jhansi swarm, and (ii) ENEWSW trending ca. $1.11 \mathrm{Ga}$ Mahoba swarm, the latter is part of the ca. 1.05-1.11 Ga LIP event (cf. Pradhan et al., 2012; Ernst, 2014; Samal et al., 2019a). Samom et al. (2018) have presented Sm-Nd mineral-whole rock age of $2104 \pm 23 \mathrm{Ma}$ for a gabbroic sill from the Proterozoic Gwalior basin (sitting north to the Bundelkhand craton). On the basis of its age similarities with the radiating Devarabanda mafic dyke 
swarm of the Dharwar craton, Samal et al. (2019a) interpreted Gwalior gabbroic sill as a part of ca. 2.08 Ga Devarabanda LIP. The Neoproterozoic Malani Igneous Suite (MIS) is identified as a silicic LIP (SLIP) and recently a representative sample of this suite from the Mirpur Granite has yielded a U-Pb zircon age of $753 \pm 9$ Ma (de Wall et al., 2018). Several other Precambrian LIP events are also present in the Indian Shield (Samal et al., 2019a,b), however there is no recent work available to share.

\section{Geochemistry}

Mineralogical and geochemical characterization of LIPs and their magmatic components helps in solving petrogenetic aspects of these rocks and allows assessment of the nature and evolution of deep mantle. An earlier review of the geochemistry of Paleoproterozoic mafic dyke swarms of the eastern Dharwar craton (EDC) was provided by Srivastava et al. (2015). Not much subsequent geochemistry has been done on the EDC mafic dykes except for Liao et al. (2019), who studied boninitic dykes of the Bhanupratappur region, central Bastar craton and the Karimnagar area, NE Dharwar craton; both these swarms emplaced ca. $2.37 \mathrm{Ga}$. These authors (Liao et al., 2019) have also discussed the petrogenesis of the boninitic dykes of the central Bastar craton and suggested that fractional crystallization was the likely cause of major element variability in these rocks. However trace element modeling result indicates their derivation from a pyroxenite mantle source near the spinel-garnet transition zone (Liao et al., 2019).

Rai et al. (2019) studied the geochemistry of undated NE-SW to ENE-WSW trending Palaeoproterozoic mafic dyke swarms from the western Dharwar craton (WDC) and identified three distinct groups, which may represent three different swarms. They compared geochemistry of these WDC mafic dykes with the dated swarms of the eastern Dharwar craton (EDC). However, apart from one geochemical Group, which has close similarities with the ca. 1.88-1.89 Ga Hampi swarm, the other two geochemical groups from the WDC cannot be geochemically correlated with any of the known mafic dykes of the EDC. It is therefore a high priority to get these WDC dykes dated as these may represent new swarms for the Dharwar craton. Sesha Sai et al. (2019) have studied petrology and mineral chemistry of a porphyritic mafic dyke from the Jonnagiri Schist Belt, EDC and based on magnetite-ilmenite solid solution pair yielded an equilibrium temperature of $\sim 756$ ${ }^{\circ} \mathrm{C}$ and oxygen fugacity of $10^{-15.6}$ atmf $_{\mathrm{O} 2}$.

Pandey and Chalapathi Rao (2019) modeled published geochemical data on 2.37, 2.21, 2.18, and $1.89 \mathrm{Ga}$ mafic dyke swarms of the EDC (cf. Srivastava et al., 2015) and suggested that their 'arc signals' resulted from coupled assimilation and fractional crystallization (AFC) processes that modified these mantle-derived melts. They also supported the involvement of thermal plumes in their genesis. However, several other workers have also supported genesis of these distinct Paleoproterzoic mafic dykes of the EDC emplacement in an intracratonic setting, but instead of crustal contamination favoured a role of metasomatized lithospheric mantle that had been modified during an earlier ancient subduction event (cf. Ernst 2014; Srivastava et al., 2015; Rai et al., 2019).

Shellnutt et al. $(2018,2019)$ presented geochemical and Nd- and Sr-isotope data on the Bastar tholeiitic dykes emplaced ca. 1.85 Ga and ca. $1.88 \mathrm{Ga}$, mostly emplaced in the northern parts of the craton. They suggest that these mafic magmatic rocks show chemical variability due to crystal fractionation and crustal contamination and do not represent primary melts. $\mathrm{Sr}$ and $\mathrm{Nd}$ isotopes and trace element data suggests derivation from partial melting of a mantle source in the spinel-garnet transition zone, which, in general, matches earlier interpretations (cf. Srivastava and Gautam, 2015). Geochemistry of these ca. 1.88$1.89 \mathrm{Ga}$ dykes is comparable with the ca. 1.88-1.89 Ga NW trending Bastanar dyke swarm from the southern Bastar craton and the ca. 1.89 Ga Boonadgin dykes from the Yilgarn craton of Western Australia (Shellnutt et al., 2018).

Srivastava et al. (2016) and Srivastava and Gautam (2016) have discussed Nd-isotope and lithogeochemistry of an early Palaeoproterozoic (ca. 2.4-2.5 Ga) high-Si high-Mg boninite-norite-diorite suite of rocks from the Bastar craton, which show the effect of crustal contamination; however, the possibility of mantle metasomatism during ancient subduction event cannot be ignored. Geochemically three varieties viz. high-Ca boninites, high-Mg norites, and high-Mg diorites are identified; the high-Ca 
boninites crystallized from a magma generated by a comparatively greater percentage of melting of a lherzolite mantle source than the source for the other two varieties. It is likely that the high-Ca boninite rocks are derived from an Archean subduction process (the Whundo-type), whereas the other two types could be products of the interaction of subduction-modified refractory mantle wedge and a plume. Hazarika et al. (2019) studied a boninitic dyke and suggested preservation of subduction-related signatures in the lithospheric mantle beneath the Bastar craton. All these boninitic dykes are thought to be associated with the Dantewara mafic dyke swarms (cf. Samal et al., 2019a,b).

Geochemical characteristics of the ca. 0.76-0.77 Ga Malani Igneous Suite (MIS), identified as a SLIP, suggest a two-stage evolution model with initial and late stage rifting and crustal extension events (de Wall et al., 2018). It is also suggested that mafic rocks of the MIS are derived from a depleted continental lithospheric source, whereas the silicic component shows low-pressure high-temperature melting. The bimodal association is due to mantle upwelling which leads to the melting of thin crust.

Srivastava and Samal (2019) studied the geochemical characteristics of Paleoproterozoic mafic intrusive rocks from the western Arunachal Himalaya, which is thought to be a part of the ca. 1.85-1.90 Ga LIP, to understand their petrogenesis and tectonic environment. Two suites of rocks identified as high titanium mafic and low titanium mafic intrusives, which were originally spatially separated at the time of their emplacement, but were tectonically juxtaposed during the Himalayan orogeny. It is suggested that these two distinct geochemical groups of the intrusive rocks were derived from discrete mantle melts; one group from $\sim 20-25 \%$ melting in the spinel stability field (thinner lithosphere), whereas the other group was derived from $\sim 5-10 \%$ melting of a similar mantle source but in garnet stability field (thicker lithosphere). Rashid et al. (2019) have also studied metabasic rocks from Lesser Himalayan sequence, western Arunachal Pradesh, for their geochemistry and presented almost similar results as observed by Srivastava and Samal (2019).

\section{Paleomagnetism}

There is a limited recent work on paleomagntism of the Precambrian LIPs. Nagaraju et al. (2018a) studied ca. $2252 \mathrm{Ma}$ (part of the Ippaguda-Dhiburahalli swarm) and ca. $2207 \mathrm{Ma}$ (part of the Devarabanda swarm) dykes of the Dharwar craton and reported paleomagnetic poles at $16^{\circ} \mathrm{S}, 299^{\circ} \mathrm{E}\left(\mathrm{dp}=13^{\circ}\right.$ anddm $\left.=15^{\circ}\right)$ and $57^{\circ} \mathrm{N}, 113^{\circ} \mathrm{E}\left(\mathrm{dp}=8^{\circ}\right.$ and $\left.\mathrm{dm}=10^{\circ}\right)$, respectively. They have also refined the existing APW path for the Dharwar craton between 2367 Ma and $1886 \mathrm{Ma}$ and reported that a major tectonic activity such as breakup of a supercontinent at 2.2 Ga may have been responsible for rapid drift of Dharwar craton between $2216 \mathrm{Ma}$ and $2207 \mathrm{Ma}$. In another publication, Nagaraju et al. (2018b) studied the $\sim 450$ km long ca. 2216 Ma N-S striking Kandlamadugu dyke swarm and reported a paleomagnetic pole at latitude $36^{\circ} \mathrm{S}$ and longitude $312^{\circ} \mathrm{E}\left(\mathrm{A} 95=7^{\circ}\right)$ for this swarm. Babu et al. (2018) have also studied the ca. 2367 Ma Bangalore-Karimnagar dyke swarm and reported possible spatial link among the Dharwar dykes (India), Widgemooltha and Erayinia dykes (Australia), Sebanga Poort dykes (Africa) and Karelian dykes (Baltica Shield). Pivarunaset al. (2018) have also added new paleomagnetic results from mafic dykes exposed in the Salem Block of the Northern Granulite Terrain (NGT) and reported that ca. 2370 Ma Bangalore-Karimnagar dyke swarm is present in the NGT with a paleomagnetic pole at $2^{\circ} \mathrm{N}$ and $73^{\circ} \mathrm{E}$ $\left(\mathrm{A} 95=14^{\circ}\right)$. In addition, this study also reveals that several of the reported paleomagnetic directions from NGT are matching with the $2.21 \mathrm{Ga}, 2.18 \mathrm{Ga}$, and $1.88 \mathrm{Ga}$ dykes of the Dharwar craton and hence support a juxtaposition of northern part of the southern India (i.e. NGT) with the Dharwar craton from at least $2370 \mathrm{Ma}$ (see Fig. 5).

Radhakrishna and Chandra (2017) reassessed the palaeomagnetic data on Proterozoic mafic dykes in the Bundelkhand and Bastar cratons and estimated the 1.466 Ga paleopole, probably belong to the Lakhna event, at $49.4^{\circ} \mathrm{N}$ and $132.9^{\circ} \mathrm{E}\left(\mathrm{A} 95=6.6^{\circ}\right)$ and 1.65 Ga paleopole at $59.6^{\circ} \mathrm{N}$ and $47.9^{\circ} \mathrm{E}\left(\mathrm{A} 95=8.1^{\circ}\right)$. They have suggested a positive linkage between the Indian Shield and Western Australia and negated the juxtaposition of India with North China/Laurentia in Columbia (Nuna) reconstructions.

Kumar et al. (2017) reported a Neoarchean Keshargaria-GhatgaonLIP from the Singhbhum Granite Complex (SGC) of the Singhbhum craton and reported at key paleomagnetic pole at $\sim 2762 \mathrm{Ma} 14 \mathrm{~N}^{\circ}$, 


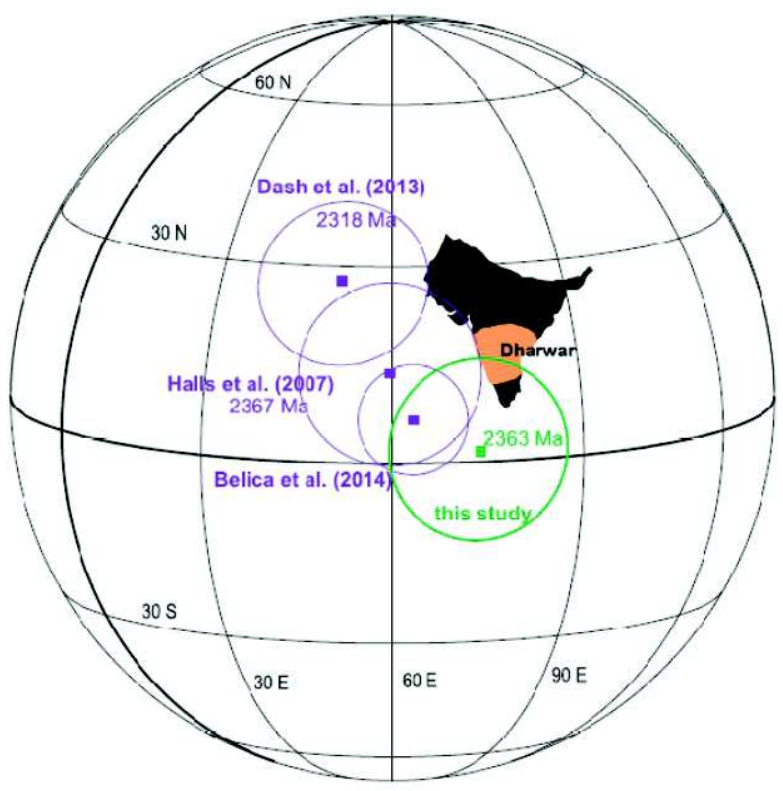

Fig. 5: Comparison of the paleomagnetic pole calculated from primary $2363 \pm 6.6$ Ma paleomagnetic direction (green) with other studies from the SouthernDharwar craton (violet) (Figure taken from Pivarunas et al., 2018)

$78 \mathrm{E}^{\mathrm{o}}(\mathrm{dp}=11, \mathrm{dm}=12)$. They have reported that the Singhbhum, Pilbara and Kaapvaal cratons were located at steep latitudes at ca. $2770 \mathrm{Ma}$ and could have been proximal to each other during this time. They have also proposed that Singhbhum craton with similar Archean geology could also have had its ancestry in the Vaalbara supercraton. Paleomagnetic studies on the WNW-ESE and emplaced ca. 1765 Ma Pipilia swarm of the SGC have also been presented (Shankar et al., 2018). They have reported the first key paleopole at $45^{\circ} \mathrm{N}, 311^{\circ} \mathrm{E}(\mathrm{dp}=5.2$ and $\mathrm{dm}=9.9)$ and proposed a paleogeographic reconstruction at ca. $1770 \mathrm{Ma}$, indicating a linkage between Baltica Craton and India for at least $\sim 370$ Ma (ca. 1770-1400 Ma) and they also supported India-North China craton spatial proximity at ca. 1770 Ma (see Fig. 6).

\section{Phanerozoic LIP}

Four prominent Phanerozoic LIP events are present in the Indian Shield, viz. (i) the early Permian Panjal, (ii) the early Cretaceous Greater Kerguelen (also named Comei-Bunbury), (iii) the late Cretaceous Madagascar, and (iv) the Cretaceous-Tertiary (Paleogene) Deccan (cf. Ernst, 2014; Shellnutt, 2017,
2018; Sensarma et al., 2018; Vijay Kumar et al., 2018; Roy and Purohit, 2018). These LIPs may or may not be associated with the Crozet, Kerguelen, Marion and Réunion hot spots (cf. Vijay Kumar et al., 2018; Roy and Purohit, 2018).

Magmatism of the Madagascar-India LIP is observed in the Madurai Block of southern India (Shaji et al., 2018). Geochemical and zircon U-Pb geochronological studies have been done for the alkali leuco gabbros from Mundanmudi area. The zircon grains from the gabbro sample yield $84.6 \pm 1.4 \mathrm{Ma}$, which is thought to be related with the rift-related tectonic setting. Another gabbroic/granophyric pluton exposed at the northern tip of the Nilgiri block, which emplaced ca. 93-94 Ma, is also associated to the Madagascar-India LIP (Marion hotspot) (Mohan et $a l ., 2016)$. They have further suggested that this magmatic event can be correlated with the post break up stage of the India-Madagascar flood basalt volcanism occurred between ca. 84 and $92 \mathrm{Ma}$ (Mohan et al., 2016; Shaji et al., 2018).

The Permian Panjal LIP (Trap), consisting of basaltic, andesitic and silicic volcanics, is emplaced ca. 290-270 Ma, mostly recognized in the northwestern Himalayan range, has been often linked with Gondwana break-up (Shellnutt, 2017, 2018; Sensarma et al., 2018; Vijay Kumar et al., 2018). It is suggested that the Panjal LIP was not derived from a mantle plume and its origin could be attributed from a passive rift system (Shellnutt, 2017, 2018). However, Shellnutt (2018) has recommended a careful study of Panjal Traps (particularly on their plutonic equivalents, geochronology, identifying the plumbing system, etc.) before having any definite conclusion regarding plume involvement or not.

The early Cretaceous Greater Kerguelen LIP covers a large area in SE Tibet, NE India, Western Australia and Antarctica and is thought to be associated with the break-up of East Gondwanalandca.132 Ma (cf. Zhu et al., 2009; Olierook et al., 2016, 2017; Singh et al., 2019). The Greater Kerguelen LIP covers a huge area and one of the largest LIPs (cf. Bryan and Ferrari, 2013; Ernst, 2014); all the contemporaneous magmatism (initial Comei-Bunbury pulse at $130 \mathrm{Ma}$ and subsequent Kerguelen pulses 118-100 Ma) of this LIP is shown in Figure 7 (Olierook et al., 2016, 2017; Singh et al., 
2019; Srivastava, 2020). Activities related to the second pulse of this Kerguelen mantle plume are well recorded in the NE Indian Shield during ca. 118-100 Ma, particularly within the Chhotanagpur Gneissic Complex (CGC) of the Singhbhum craton and the Shillong Plateau-Mikir Hills (SPMH) Shield area, which include (i) ultrapotassic, (ii) silicate (ultramaficalkaline)-carbonatite complexes, and (iii) mafic intrusions (Srivastava et al., 2016d, 2019d; Srivastava, 2020).

Srivastava et al. (2016d) studied an early Cretaceous lamprophyre dyke exposed near Rongjeng, East Garo Hills, Shillong plateau and suggested its potassic affinity crystallizing in hydrous alkaline magmas, which is well comparable with the nearby Jasra potassic intrusion, but is distinctly different from the Damodar Valley lamproites as well as the Sung Valley carbonatitic-ijolitic intrusion. Several new in-situ U-Pb ages on zircon and perovskite, and $\mathrm{Sr}-\mathrm{Nd}-\mathrm{Hf}$ isotope data on zircon, perovskite, baddeleyite, apatite, titanite and calcite in Sung Valley and Jasra ultramafic alkaline(carbonatite) intrusions have been reported (Srivastava et al., 2019d). These high quality isotopic data suggest that the Sung Valley and the Jasra intrusions evolved through different petrogenetic processes. They were emplaced between $\sim 102-109 \mathrm{Ma}$, well after the tholeiitic event ( $\sim 117-118 \mathrm{Ma})$ recorded in the region, which suggest a different genetic history. Furthermore, the Sr-Nd-Hf isotopic compositions suggest lowpressure crustal contamination, crystal accumulation and fractional crystallization, rather than mantlederived heterogeneity. It is recommended that different magmatic rocks of the Damodar Valley and the Antarctic ultramafic lamprophyres result from a variable extent of pre-Mesozoic metasomatism in the lithospheric mantle of eastern Gondwana (Srivastava et al., 2019d). It is further explained that eruption of the Sylhet-Rajmahal tholeiitic basalts, mafic dykes and lamproites at ca. 112-118 Ma have a possible genetic connection with a mantle plume, but that the relatively younger ( 101-109 Ma) alkaline carbonatite complexes and lamprophyre of the Shillong Plateau are likely to have their derivation from distinct magma batches generated through the depleted asthenosphere and lithosphere with negligible contribution from the Kerguelen mantle plume. The latter, however, possibly provided additional heat necessary to melt the source regions (Olierook et al., 2017: Srivastava et al., 2019d; Srivastava, 2020).

The other Phanerozoic LIP recorded from the Indian Shield is the well-known Cretaceous-Tertiary (Paleogene) Deccan LIP. A considerable amount of works on this LIP has been done in recent years. However, here we report only those publications which have direct connection with the Deccan LIP; this is because a report on the Deccan Volcanic Province is separately presented in this volume (Kumar et al, 2020). Sprain et al. (2019) studied the Deccan Trap volcanism to understand the late Cretaceous environmental impacts and its contribution to the Cretaceous-Tertiary (Paleogene) boundary (KTB/ $\mathrm{KPB}$ ) ecosystem crisis. On the basis of high-precision $\mathrm{Ar}^{40} / \mathrm{Ar}^{39}$ age data, they preclude the prior interpretation of three discrete large pulses and instead conclude that $>90 \%$ of the Deccan eruptions in $<1$ million years, with $\sim 75 \%$ emplaced post-KPB. Their model improved our understanding on the Deccan volcanic fluxes with observed climate changes and to understand the specific role Deccan volcanism in the KPB mass extinction; similar to the results obtained earlier by Schoene et al. (2015) i.e. the Deccan Traps contributed to the Cretaceous environmental change and its role in the marine and terrestrial mass extinctions. It is further strengthened by new U-Pb zircon geochronology (Schoene et al., 2019). They established four high-volume Deccan eruptive periods in which major eruptions were before and after the K-Pg extinction that supports both catastrophic events as drivers of environmental worsening.

The $\mathrm{Sr}$ and $\mathrm{Nd}$ isotopic signature of volcanic basalts of the Deccan LIP suggest its derivation from a heterogeneous mantle source, probably mixing of more than one distinct isotopic reservoirs and some degree of crustal assimilation (Manu Prasanth et al., 2019). They further stated that the main phase of Deccan LIP could be linked with global warming, ocean acidification, climate effects, and mass extinction.

The Geological Society London has recently published a Special Issue on the Tectonics of the Deccan Large Igneous Province (Mukherjee et al., 2017). Articles in this Special Issue deal with different aspects, but mostly on structural geology, related to the Deccan volcanism (Rajaram et al., 2017; Maurya 


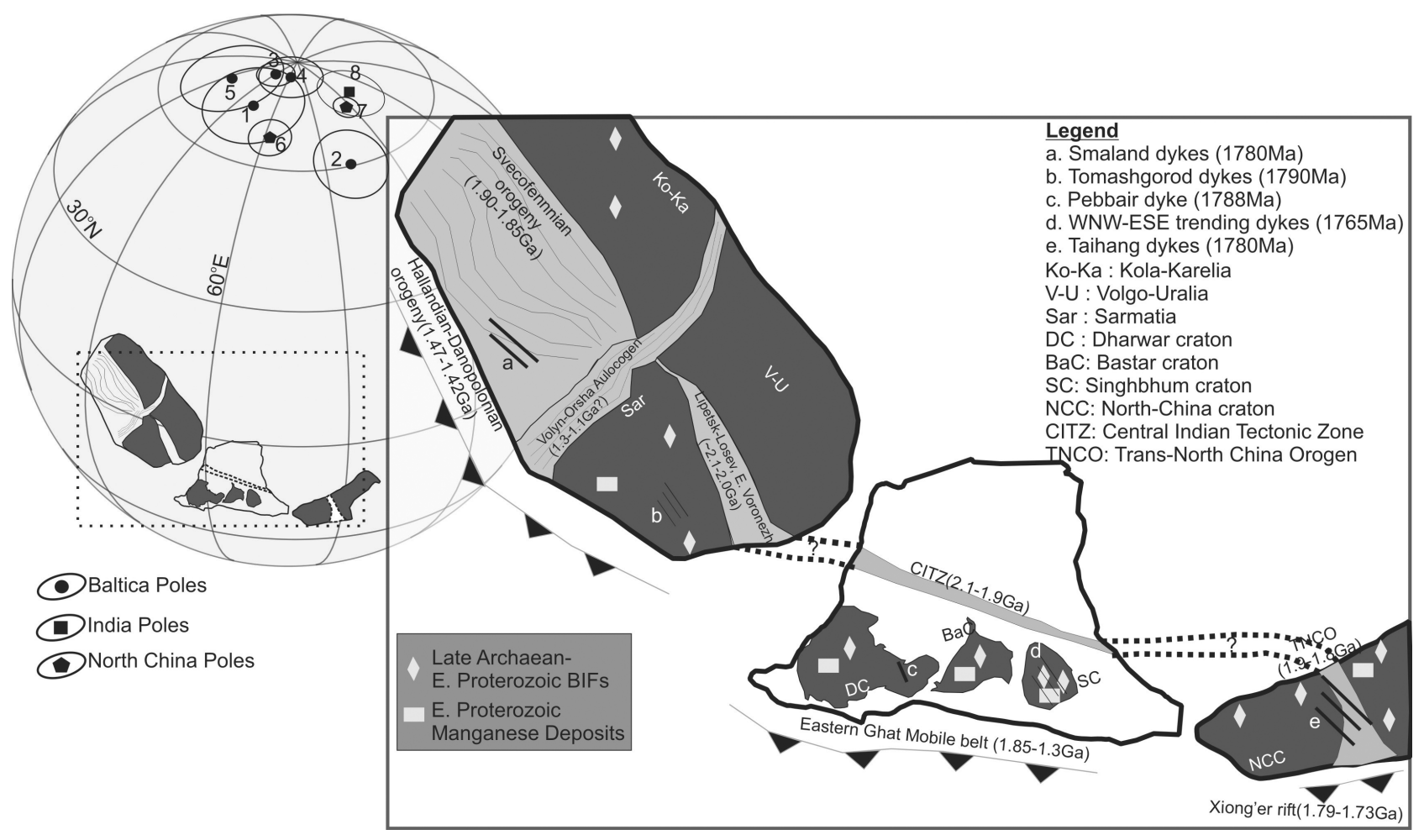

Fig. 6: Paleogeographic reconstruction at $1.77 \mathrm{Ga}$ (Figure taken from Shankar et al., 2018)

et al., 2017, Misra and Mukherjee, 2017; Babar et al., 2017). Kale et al. (2017) provided an overview on the relationship between geomorphology and Deccan plateau uplift. Ju et al. (2017) have used mafic dyke swarms associated with the Deccan LIP and showed that they follow trends of several rift zones in peninsular India, which are thought to have existed since Archean, to discuss effects of mechanical layering and regional tension on dyke emplacement within the Narmada rift zone. They emphasized that the distribution of maximum principal tensile stresses was altered by mechanical layering and/or regional tension, which has led to variations in potential dyke propagation pathways. Three sets of dykes, mostly feeder dykes associated with Deccan LIP, are identified; these are (i) $65.6 \mathrm{Ma}$, (ii) $65 \mathrm{Ma}$, and (iii) 64-63 Ma, which have been studied for their structural analyses (Misra and Mukherjee, 2017). Pathak et al. (2017), on the basis of Virtual Geomagnetic Pole (VGP), obtained by palaeomagnetic measurements of 37 lava flows from the eastern Deccan Volcanic Province, and concluded that the eastern and western Deccan Traps were erupted for a shorter period close to the Cretaceous-Palaeogene boundary (KPB).
Buchan and Ernst (2019) presented very exciting results on the different mafic dykes of the Deccan LIP and classified them as (i) radiating dykes and (ii) circumferential dykes; some other dykes, whose trends are not matching to radiating or circumferential swarms, are also reported. The radiating dyke swarm particularly belongs to the Narmada-Tapi, the West Coast, and the Saurashtra (Kathiawar) region subswarms. They further stated that the dykes that are perpendicular to these sub-swarms of the radiating system are part of a giant circumferential dyke swarm with an outer diameter of $>600 \mathrm{~km}$ and an arc of $\sim 220^{\circ}$ and they locate the centre of this circumferential swarm near the focus of the radiating swarm in the Gulf of Cambay, which falls along the Réunion mantle plume track (see Fig. 8). Precise radiometric dating of mafic dykes belonging to both of these swarms is recommended for better understanding (Buchan and Ernst, 2019).

High-Mg dolerite dykes (identified as picrodolerites), exposed in the central part of the Deccan LIP, have been reported and studied for their geochemistry (Dongre et al., 2018). The mineral chemistry of different constituent minerals and the 


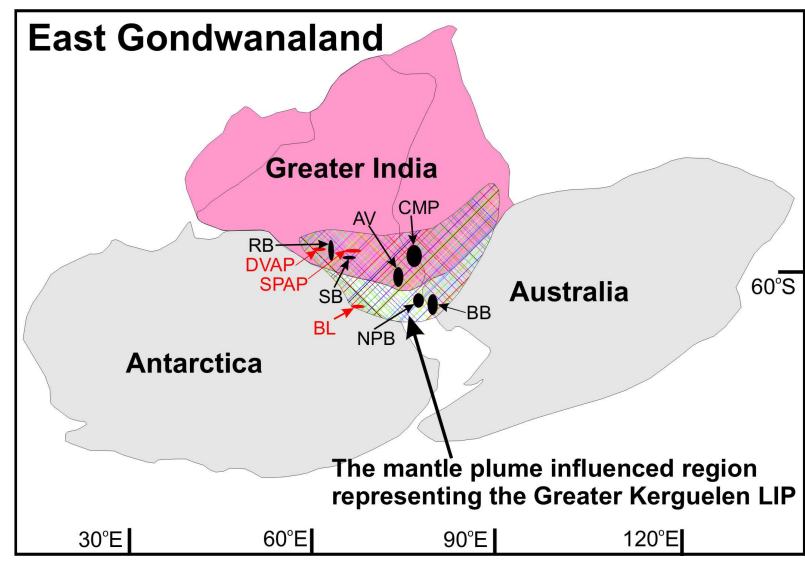

Fig. 7: Simplified plate tectonic reconstruction (modified from Zhu et al., 2009; Singh et al., 2019) of East Gondwanaland, showing major magmatic events during 100-140 Ma which are supposed to be part of the Greater Kerguelen LIP. Location/events: AV, Abor volcanic; BB, Bunbury basalt; BL, Beaver Lake lamprophyres; CMP, Comei magmatic province; DVAP, Damodar Valley alkaline province; NPB, Naturaliste Plateau basalt; RB, Rajmahal basalts; SB, Sylhet basalts; SPAP, Shillong Plateau alkaline province (Figure taken from Srivastava, 2020)

high $\mathrm{MgO}$ nature of these picro-dolerite dykes are indicative of their genesis through plume magmatism, formed by high degrees of partial melting and also inferred that these are the source of alkali basalt flows, whereas tholeiitic dykes of the western and northern Deccan-related dyke swarms cannot represent the feeders for the alkali basalt flows (Dongre et al., 2018).

\section{Summary}

The descriptions above clearly demonstrate a remarkable amount of work done on Large Igneous Provinces (LIPs) and their components for the Indian context in space and time since 2016. This will definitely be useful in understanding geodynamics of the Indian Shield and supercontinents through time and also identifying the avenue for new research. Some important observations are :

1. Broadly, the Indian Shield comprises twelve prominent LIP events during Precambrian and on the basis of new high-precision $\mathrm{U}-\mathrm{Pb}$ data, a number of distinct magmatic events, mostly in form of mafic dyke swarms and continental flood basalts, are identified in the different Archean cratons of the Indian Shield.

2. A $30^{\circ}$ relative rotation in trend of mafic dyke swarms (older than $2.08 \mathrm{Ga}$ ) and other older geological features between northern and southern Dharwar cratons has been identified. This tectonic probably formed through either orthogonal extension of its eastern convex side or a zone of pervasive dextral shearing affecting its southern portion. This resultant change in dyke swarm patterns emplaced before $2.08 \mathrm{Ga}$ swarm; radiating swarms converted to linear swarms.

3. In general, geochemical characteristics of the Paleoproterozoic mafic dykes suggest genesis through mantle melts and their emplacement in an intracratonic setting. However, the role of a previously modified metasomatized lithospheric mantle due to some ancient subduction event cannot be ignored.

4. An early Cretaceous Greater Kurguelen LIP event with a time span of $\sim 35$ myrs $(\sim 100-135$ $\mathrm{Ma}$ ) is identified, which covers different magmatic events recorded in SE Tibet, NE India, Western Australia and Antarctica. The magmatic activities recorded in the Chhotanagpur Gneissic Complex the Shillong Plateau-Mikir Hills of the NE Indian Shield are part of the Greater Kurguelen LIP. This also includes Rajmahal-Sylhet-Bengal and Abor volcanics.

5. New geochronological data on the Deccan Trap volcanism helped to improve our understanding on how the Deccan volcanic fluxes link with observed climate changes and actually to understand the specific role of Deccan volcanism in the KPB mass extinction.

6. A giant circumferential dyke swarm with an outer diameter of $>600 \mathrm{~km}$ and an arc of $\sim 220^{\circ}$ has been identified in the Deccan volcanic province. It is predicted that the centre of this circumferential swarm is situated near the focus of the radiating swarm in the Gulf of Cambay, which falls along the Réunion mantle plume track. However, further study, particularly geochronological and paleomagnetic, is recommended to come to any final conclusion. 


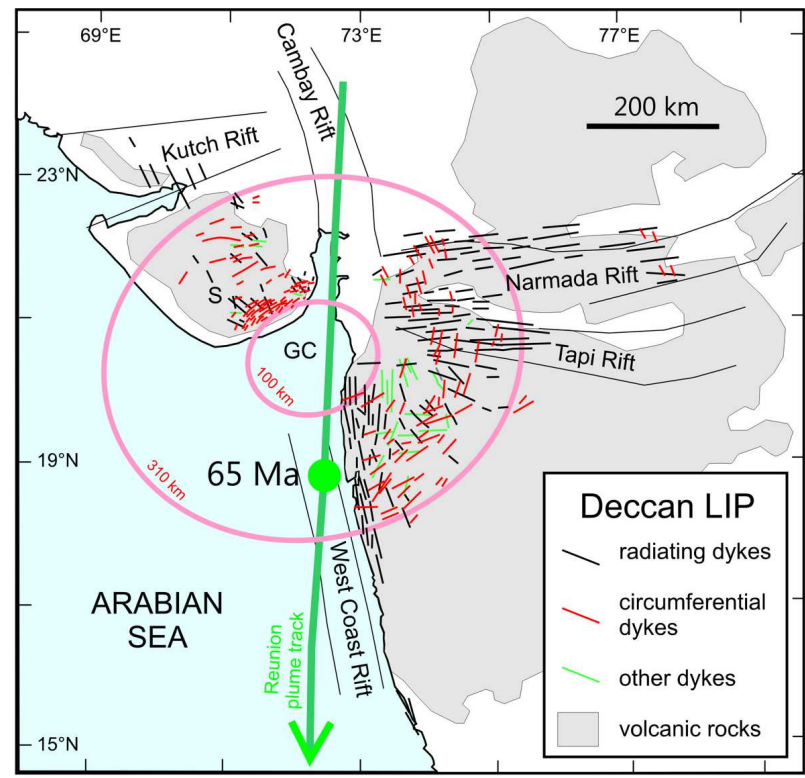

Fig. 8: Circumferential and radiating dykes of the ca. $65 \mathrm{Ma}$ Deccan LIP, India. Pink circles indicate the approximate outer and inner dimensions of the circumferential swarm. The centre of the circumferential swarm and the focus of the radiating swarm are similar and fall roughly on the Reunion plume track. S, Saurashtra (Kathiawar) region; GC, Gulf of Cambay. Figure taken from Buchan and Ernst, 2019

7. All of these important researches could be the basis for critical new tests for paleogeographic reconstructions of supercontinents and paleocontinents in Earth's history. The new paleomagnetic and geochronological data on the different LIPs of the Indian Shield have helped to identify ancient supercontinents.

\section{References}

Babar M D, Kaplay R D, Mukherjee S and Kulkarni P S (2017) Evidence of the deformation of dykes from the Central Deccan Volcanic Province, Aurangabad, Maharashtra, India Geol Soc Spec Publ 445 337-353

Babu N R, Venkateshwarlu M, Shankar R, Nagaraju E and Parashuramulu V (2018) New paleomagnetic results on $\sim 2367$ Ma Dharwar giant dyke swarm, Dharwar craton, southern India: implications for Paleoproterozoic continental reconstruction J Earth Syst Sci 1273

Belica M E, Piispa E J, Meert J G, Pesonen L J, Plado J, Pandit M K, Kamenov G D and Celestino M (2014) Paleoproterozoic mafic dyke swarms from the Dharwar

\section{Acknowledgements}

We thank the Indian National Science Academy, particularly, D.M. Banerjee (Delhi University) and A.K. Jain (Roorkee) for their kind invitation and for providing us a wonderful opportunity to write the status report. We also thank N.V. Chalapathi Rao for providing constructive comments and suggestions on the earlier version, which helped us to improve this presentation. We tried a sincere effort to incorporate and discuss as many references as we can and omissions, if any, are inadvertent. Financial support received from different funding agencies of the Government of India through the Ministry of Earth Sciences (MoES/16/10/11-RDEAS), the Council of Scientific and Industrial Research (24(0348)/17/EMR II), and the Science and Engineering Research Board (EMR/2016/000169) to RKS is thankfully acknowledged. REE is partially supported by Russian Mega-Grant 14.Y26.31.0012 and Canadian NSERC grant CRDPJ 523131-17.

craton; paleomagnetic poles for India from 237 to $188 \mathrm{Ga}$ and rethinking the Columbia supercontinent Precamb Res 244 100-122

Bleeker W and Ernst R E (2006) Short-lived mantle generated magmatic events and their dyke swarms: the key unlocking Earth's paleogeographic record back to $26 \mathrm{Ga}$;(Eds: Hanski E, Mertanen S, Ramo T, Vuollo J ) Dyke Swarms - Time Markers of Crustal Evolution, Taylor \& Francis, London 3-26

Bryan S E and Ferrari L (2013) Large igneous provinces and silicic large igneous provinces: progress in our understanding over the last $25 \mathrm{yr}$ Geol Soc America Bull 125 1053-1078

Buchan K L and Ernst R E (2019) Giant circumferential dyke swarms: catalogue and characteristics; (Eds: Srivastava R K, Ernst R.E, Peng P) Dyke Swarms of the World: A Modern Perspective, Springer Nature Singapore Pte Ltd $1-44$

Chalapathi Rao N V, Atiullah, Burgess R, Nanda P, Choudhary A K, Sahoo S, Lehmann B and Chahong N (2016) Petrology, ${ }^{40} \mathrm{Ar} /{ }^{39} \mathrm{Ar}$ age, $\mathrm{Sr}-\mathrm{Nd}$ isotope systematics, and geodynamic significance of an ultrapotassic (lamproitic) dyke with affinities to kamafugite from the eastern-most margin of the Bastar Craton, India Mineral Petrol 110 269-293

de Wall H, Pandit M K, Donhauser I, Schöbel S, Wang W and Sharma K K (2018) Evolution and tectonic setting of the Malani - Nagarparkar Igneous Suite: A Neoproterozoic 
Silicic-dominated Large Igneous Province in NW India-SE Pakistan J Asian Earth Sci 160 136-158

Dongre A, Viljoen K S and Rathod A (2018) Mineralogy and geochemistry of picro-dolerite dykes from the central Deccan Traps flood basaltic province, India and their geodynamic significance Mineral Petrol 112 267-277

Ernst R E (2014) Large Igneous Provinces. Cambridge University Press, Cambridge

Ernst R E and Jowitt S M (2017) Multi-commodity, multi-scale exploration targeting using the Large Igneous Province record Geol Surv Western Australia Record 2017/6 41-44

Ernst R E and Srivastava R K (2008) India's place in the Proterozoic world: constraints from the Large Igneous Province (LIP) record; (Eds: Srivastava R K, Sivaji C, Chalapathi Rao N V) Indian Dyke: Geochemistry, Geophysics and Geochronology, NarosaPubl House Pvt Ltd New Delhi 413-445

Ernst R E and Youbi N (2017) How Large Igneous Provinces affect global climate, sometimes cause mass extinctions, and represent natural markers in the geological record Palaeogeog Palaeoclimat Palaeoeco 478 30-52

Hazarika B, Malpe D B and Dongre A (2019) Petrology and geochemistry of a boninite dyke from the western Bastar craton of central India J Earth Syst Sci 12832

Ju W, Hou G, Hari K R (2017) Dyke emplacement in the Narmada rift zone and implications for the evolution of the Deccan Traps Geol Soc Spec Publ 445 297-315

Kale V S, Dole G, Upasani D and Pillai S P (2017) Deccan Plateau uplift: insights from parts of Western Uplands, Maharashtra, India Geol Soc Spec Publ 445 11-46

Kumar A, Parashuramulu V, Shankar R and Besse J (2017) Evidence for a Neoarchean LIP in the Singhbhum craton, eastern India: implications to Vaalbara supercontinent Precamb Res 292 163-174

Kumar A, Pal S and Shrivastava J P (2020) Contemporary researches and issues related to the Deccan volcamism Proc Indian Acad Sci (this volume)

Liao A C, Shellnutt J G, Hari K R, Denyszyn S W, Vishwakarma $\mathrm{N}$ and Verma C B (2019) A petrogenetic relationship between $2.37 \mathrm{Ga}$ boninitic dyke swarms of the Indian Shield: Evidence from the Central Bastar Craton and the NE Dharwar Craton Gond Res 69 193-211

Manu Prasanth M P, Hari K R and Santosh M (2019) Tholeiitic basalts of Deccan large igneous province, India: an overview Geol J (in press); DOI: 101002/gj3497

Maurya D M, Chowksey V, Patidar A K and Chamyal L S (2017) A review and new data on neotectonic evolution of active faults in the Kachchh Basin, Western India: legacy of postDeccan Trap tectonic inversion Geol Soc Spec Publ 445 237-268

Mazumder R and Chaudhuri T (2019) Precambrian mafic dyke swarms in the Singhbhum craton (eastern India) and their links with dyke swarms of the eastern Dharwar craton (southern India) - Discussion Precamb Res 329 18-22

Misra A A and Mukherjee S (2017) Dyke-brittle shear relationships in the Western Deccan Strike-slip Zone around Mumbai (Maharashtra, India) Geol Soc Spec Publ 445 269-295

Mohan M R, Shaji E, Satyanarayanan M, Santosh M, Tsunogae T, Yang Q Y and Dev S D (2016) The Ezhimala igneous complex, southern India: Possible imprint of late Cretaceous magmatism within rift setting associated with IndiaMadagascar separation J Asian Earth Sci 121 56-71

Mukherjee S, Misra A A, Calvès G and Nemèok M (2017) Tectonics of the Deccan large igneous province: an introduction Geol Soc Spec Publ 445 1-9

Nagaraju E, Parashuramulu V, Ramesh Babu N and Narayana A C (2018a) A 2207 Ma radiating mafic dyke swarm from eastern Dharwar craton, Southern India: drift history through Paleoproterozoic Precamb Res 317 89-100

Nagaraju E, Parashuramulu V, Kumar A and Srinivas Sarma D (2018b) Paleomagnetism and geochronological studies on a $450 \mathrm{~km}$ long $2216 \mathrm{Ma}$ dyke from the Dharwar craton, southern India Phys Earth Planet Interiors 274 222-231

Nehru C E and Sikka D B (2018) Petrochemistry of dyke rocks from the Paleoproterozoic Malanjkhand porphyry coer mine, India: a possible link to the mineralization $J \mathrm{Al}$ Geochem 20 1-28

Olierook H K H, Jourdan F, Merle R E, Timms N E, Kusznir N J and Muhling J (2016) Bunbury Basalt: Gondwana breakup products or earliest vestiges of the Kerguelen mantle plume? Earth Planet Sci Lett 440 20-32

Olierook H K H, Merle R E and Jourdan F (2017) Toward a Greater Kerguelen Large Igneous Province: Evolving mantle source contributions in and around the Indian Ocean Lithos 282-283 163-172

Pandey A and Chalapathi Rao N V (2019) Coupled assimilation and fractional crystallization (AFC) and mantle plume source(s) contribution in the generation of Paleoproterozoic mafic dykes of the eastern Dharwar craton, southern India J Geol Soc India 93 157-162

Pathak V, Patil S K and Shrivastava J P (2017) Tectonomagmatic setting of lava packages in the Mandla lobe of the eastern Deccan volcanic province, India: paleomagnetism and magnetostratigraphic evidence Geol Soc Spec Publ 445 
69-94

Peng P, Ernst R E, Hou G T, Söderlund U, Zhang S H, Hamilton M, Xu Y G, Denyszyn S, Mege D, Pisarevsky S, Srivastava R K and Kusky T M (2016) Dyke swarms: keys to paleogeographic reconstructions Sci Bull 6 1669-1671

Peng P, Ernst R E, Söderlund U and Hamilton M (2019) Dyke Swarms: Keys for Precambrian Paleogeographic Reconstruction-Proceedings of the Seventh International Dyke Conference Precamb Res 329 1-4

Pivarunas P F, Meert J G, Pandit M K and Sinha A (2018) Paleomagnetism and geochronology of mafic dykes from the Southern Granulite Terrane, India: Expanding the Dharwar craton southward Tectonopys (in press), DOI: https://doiorg/101016/jtecto201801024

Pradhan V R, Meert J G, Pandit M K, Kamenov G and Mondal M EA(2012) Paleomagnetic and geochronological studies of the mafic dyke swarms of Bundelkhand craton, central India: implications for the tectonic evolution and paleogeographic reconstructions Precamb Res 198-199 5176

Radhakrishna T and Chandra R (2017) Geodynamic significance of the updated Statherian-Calymmian (at c 165 and 146 $\mathrm{Ga}$ ) palaeomagnetic results from mafic dykes of the Indian shield Curr Sci 112811

Rai A K, Srivastava R K, Samal A K and Sesha Sai V V (2019) Geochemistry, petrogenesis and geodynamic implications of NE-SW to ENE-WSW trending Paleoproterozoic mafic dyke swarms from southern region of the western Dharwar craton Geol J (in press); DOI: 101002/gj3493

Rajaram M, Anand S P, Erram V C and Shinde N (2017) Insight into the structures below the Deccan Trap-covered region of Maharashtra, India from geopotential data Geol Soc Spec Publ 445 219-236

Rashid S A, Ganai J A, Bhat I M and Islam N (2019) Geochemistry, petrogenesis and tectonic significance of the Proterozoic mafic dykes from the Bomdila area, NE Lesser Himalaya, India;(Eds: Srivastava R K, Ernst R E, Peng P) Dyke Swarms of the World: A Modern Perspective,Springer Nature Singapore Pte Ltd 415-438

Roy A and Purohit R (2018) Indian shield: Precambrian evolution and Pahnerozoic reconstitution. Elsevier

Samal A K, Srivastava R K, Ernst R E and Söderlund U (2019a) Neoarchean-Mesoproterozoic Mafic Dyke Swarms of the Indian Shield Made Using Google Earth ${ }^{\mathrm{TM}}$ Images and ArcGIS $^{\text {TM }}$, and Links with Large Igneous Provinces; (Eds: Srivastava R K, Ernst R E, Peng P) Dyke Swarms of the World: A Modern Perspective, Springer Nature Singapore Pte Ltd 335-390
Samal A K, Srivastava R K, Ernst R E and Söderlund U (2019b) Precambrian large igneous province record of the Indian Shield: an update based on extensive U-Pb dating of mafic dyke swarms LIP of the Month March 2019; URL: http:/ /wwwlargeigneousprovincesorg/19mar

Samom J D, Ahmad T and Choudhary, A K (2018) Geochemical and $\mathrm{Sm}-\mathrm{Nd}$ isotopic constraints on the petrogenesis and tectonic setting of the Proterozoicmafic magmatism of the Gwalior Basin, central India: the influence of Large Igneous Provinces on Proterozoic crustal evolution Geol Soc London Spec Publ 463 243-268

Santosh M, Hari K R, He X-F, Han Y-S and Manu Prasanth M P (2018) Oldest lamproites from peninsular India track the onset of Paleoproterozoic plume-induced rifting and the birth of large igneous province Gond Res 55 1-20

Schoene B, Samperton K M, Eddy M P, Keller G, Adatte T, Bowring S A, Khadri S F R and Gertsch B (2015) U-Pb geochronology of the Deccan Traps and relation to the end-Cretaceous mass extinction Science 347 182-184

Schoene B, Eddy M P, Samperton K M, Keller B, Keller G, Adatte T, Khadri F R (2019) U-Pb constraints on pulsed eruption of the Deccan Traps across the end-Cretaceous mass extinction Science $\mathbf{3 6 3}$ 862-866

Sesha Sai V V, Mahapatro S N, Bhattacharjee S, Khanna, T C and Korakoa M M (2019) Petrology and mineral chemistry of a porphyritic mafic dyke, Jonnagiri Schist Belt, eastern Dharwar craton, India: implications for its magmatic origin; (Eds: Srivastava R K, Ernst R E, Peng P) Dyke Swarms of the World: A Modern Perspective, Springer Nature Singapore Pte Ltd 391-414

Sensarma S, Storey B C and Malviya V P (2018) Gondwana large igneous provinces (LIPs): distribution, diversity and significance In: Large Igneous Provinces from Gondwana and Adjacent Regions; (Eds: Sensarma S, Storey, B C), Geol Soc London SpecPubl 463 1-16

Shankar R, Vijayagopal Ba and Kumar A (2014) Precise Pb-Pb baddeleyite ages of $1765 \mathrm{Ma}$ for a Singhbhum 'newer dolerite' dyke swarm Curr Sci 106 1306-1310

Shankar R, Sarma D S, Babu N R and Parashuramulu V (2018) Paleomagnetic study of 1765 Ma dyke swarm from the Singhbhum Craton: Implications to the paleogeography of India J Asian Earth Sci 157 235-244

Shaji E, Santosh M, Li S-S, Manikyamba C, Tsunogae T, Dhanil Dev S G, Panicker A G, Singh Th D and Subramanyam K V S (2018) Buds of Santonian magmatism associated with Marion hotspot in southern India Geol J (in press); DOI: 101002/gj3405

Shellnutt J G (2017) The early Permian Panjal Traps LIP of the 
Month September 2017; URL: http:// wwwlargeigneousprovincesorg/17sep

Shellnutt J G (2018) The Panjal Traps In: Large Igneous Provinces from Gondwana and Adjacent Regions; (Eds: Sensarma S, Storey, B C), Geol Soc London Spec Publ 463 59-86

Shellnutt J G, Hari K R, Liao A C, Denyszyn S W and Vishwakarma N (2018) A 188 Ga giant radiating mafic dyke swarm across Southern India and Western Australia Precamb Res $\mathbf{3 0 8}$ 58-74

Shellnutt J G, Hari K R, Liao A C, Denyszyn S W, Vishwakarma N and Deshmukh S D (2019) Petrogenesis of the 185/ Ga Sonakhan mafic dyke swarm, Bastar Craton, India Lithos 334-335 88-101

Sheard S, Rasmussen B, Zi J W, Somasekhar V, Sarma D S, Mohan M R, Krape• B, Wilde S A, and McNaughton N J (2017) Sedimentation and magmatism in the Paleoproterozoic Cuddapah Basin, India, Consequences of lithospheric extension Gond Res 48 153-163

Singh A K, Chung Sun-Lin and Bikramaditya Singh R K, Lee Hao-Yang and Khogenkumar S (2019) Zircon geochronology, Hf isotopic compositions and petrogenetic study of Abore volcanic rocks of Eastern Himalayan syntaxis, Northeast India: implications for eruption during nreackup of Eastern Gondwana Geol $J$ (in press); DOI: 101002/gj3477

Söderlund U, Bleeker W, Demirer K, Srivastava R K, Hamilton M A, Nilsson M, Pesonen L, Samal A K, Jayananda M, Ernst R E and Srinivas M (2019) Emplacement ages of Paleoproterozoic mafic dyke swarms in eastern Dharwar craton, India: implications for paleoreconstructions and evidence for $\mathrm{a} \sim 30^{\circ}$ internal block rotation Precamb Res 329 26-43

Sprain C J, Renne P R, Vanderkluysen L, Pande K, Self S and Mittal T (2019) The eruptive tempo of Deccan volcanism in relation to the Cretaceous-Paleogene boundary Science $363866-870$

Srivastava RK (2011) Dyke Swarms: Keys for Geodynamic Interpretation. Springer-Verlag, Heidelburg

Srivastava R K (2020) Early Cretaceous alkaline/ultra-alkaline and carbonatite magmatism in the Indian Shield - A review: implications for a possible remnant of the Greater Kerguelen large igneous provinces Episodes (https:// doi.org/10.18814/epiiugs/2020/020016)

Srivastava R K and Gautam G C (2015) Geochemistry and petrogenesis of Paleo-Mesoproterozoic mafic dyke swarms from northern Bastar craton, central India: Geodynamic implications in reference to Columbia supercontinent Gond Res 28 1061-1078
Srivastava R K and Gautam G C (2016) Petrogenesis and tectonic significance of an early Paleoproterozoic high-Mg boninitenorite-diorite suite of rocks from the Bastar craton, central India $7^{\text {th }}$ Int Dyke Conf, Beijing, China Acta Geol Sinica 90 (Sul 1) 116

Srivastava R K and Samal A K (2019) Geochemical characterization, petrogenesis, and emplacement tectonics of Paleoproterozoic high-Ti and low-Ti mafic intrusive rocks from the western Arunachal Himalaya, northeastern India and their possible relation to the $\sim 1.9$ Ga LIP event of the Indian shield Geol J 54 245-265

Srivastava R K, Ernst R E, Hamilton M A and Bleeker W (2010) Precambrian large igneous provinces (LIPs) and their dyke swarms: new insights from high-precision geochronology, paleomagnetism and geochemistry Precamb Res (Spec Issue) 183 379-668

Srivastava R K, Samal A K and Gautam G C (2015) Geochemical characteristics and petrogenesis of four Palaeoproterozoic mafic dike swarms and associated large igneous provinces from the eastern Dharwar craton, India Intern Geol Rev 57 $1462-1484$

Srivastava R K, Samal A K and Ernst R E (2016a) Mapping the dyke swarms emplaced within the different Archean cratons of the Indian Shield using Google ${ }^{\mathrm{TM}}$ Earth Images and

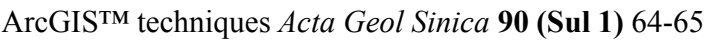

Srivastava R K, Söderlund U, Ernst R E, Mondal S K and Samal A K (2016b) Neoarchaean-palaeoproterozoic mafic dyke swarms from the singhbhum granite complex, singhbhum craton, eastern india: implications for identification of large igneous provinces and their possible continuation on other formerly adjacent crustal blocks Acta Geol Sinica 90 (Sul 1) $17-18$

Srivastava R K, Pimentel M M and Gautam G C (2016c) Ndisotope and geochemistry of an early Palaeoproterozoic high-Si high-Mg boninite-norite suite of rocks in the southern Bastar craton, central India: petrogenesis and tectonic significance Intern Geol Rev 58 1596-1615

Srivastava R K, Melluso L and Sinha A K (2016d) Petrogenesis of an early Cretaceous potassic lamprophyre dyke from Rongjeng, East Garo Hills, Shillong plateau, north-eastern India Curr Sci 110 649-658

Srivastava R K, Ernst R E and SamalA K (2018) Large igneous province (LIP) records of the Indian shield and prospects for associated metallogeny Abtract Vol, Resources for Future Generations, Vancouver, Canada, Abst No 1386

Srivastava R K, Ernst R E and Peng P (2019a) Dyke Swarms of the World: A Modern Perspective Springer Nature Singapore Pte Ltd, 492 
Srivastava R K, Söderlund U, Ernst R E, Mondal S K and Samal A K (2019b) Precambrian mafic dyke swarms in the Singhbhum craton (eastern India) and their links with dyke swarms of the eastern Dharwar craton (southern India) Precamb Res 329 5-17

Srivastava R K, Söderlund U, Ernst R E, Mondal S K and Samal A K (2019c) Precambrian mafic dyke swarms in the Singhbhum craton (eastern India) and their links with dyke swarms of the eastern Dharwar craton (southern India) reply Precamb Res 329 23-25

Srivastava R K, Guarino V, Fu-Yuan W, Melluso L and Sinha A K (2019d) Evidence of sub-continental lithospheric mantle sources and open-system crystallization processes from in-situ U-Pb ages and $\mathrm{Nd}-\mathrm{Sr}-\mathrm{Hf}$ isotope geochemistry of the Cretaceous ultramafic-alkaline-(carbonatite) intrusions from the ShillongPlataeu, North-Eastern India Lithos 330331 108-119
Stark J C, Wang X, Denyszyn S W, Li Z-X, Rasmussen B, Zi JWSheard S and Liu Y (2019) Newly identified 1.89/ Ga mafic dyke swarm in the Archean Yilgarn Craton, Western Australia suggests a connection with India Precamb Res 329 156-169

Vijaya Kumar K, Laxman M B and Nagaraju K (2018) Mantle source heterogeneity in continental mafic Large Igneous Provinces: insights from the Panjal, Rajmahal and Deccan basalts, India Geol Soc Spec Publ 463 87-116

Zhu D-C, Chung S-L, Mo X-X, Zhao Z-D, Niu Y, Song B and Yang Y-H (2009) The 132 Ma Comei-Bunbury large igneous province: remnants identified in present-day southeastern Tibet and southwestern Australia: Geology 37 583-586. 